Faculty of Law 'Iustinianus Primus', University 'Ss. Cyril and Methodius'

UDK: 331.1 (497.17:4-672EU) in Skopje (Macedonia)

Рад примљен: 30.09.2018.

Aleksandar Ristovski, PhD

Assistant Professor,

Faculty of Law 'Iustinianus Primus', University 'Ss. Cyril and Methodius'

in Skopje (Macedonia)

\title{
PROTECTION OF EMPLOYEES' RIGHTS IN THE EVENT OF COLLECTIVE REDUNDANCIES AND TRANSFER OF UNDERTAKINGS: Key Aspects of Harmonization between the EU and Macedonian Labour Law ${ }^{* *}$
}

\begin{abstract}
Taking into account the obligations arising from the Stabilization and Association Agreement of 2001 (concluded between European Communities and their Member-States and Republic of Macedonia), the country is conducting a continuous harmonization of its legal order with the EU law, including the legal regulations of the so-called "social" Acquis communautaire. In this regard, the authors of the paper shall analyze the key aspects of the implementation of Directive 98/59/EC on collective redundancies and Directive 2001/23/EC on safeguarding of employees' rights in the event of transfers of undertakings, businesses, parts of undertakings or businesses within the labour legislation of Republic of Macedonia, with a particular
\end{abstract}

\footnotetext{
*tonikalamatiev@yahoo.com

a.ristovski@pf.ukim.edu.mk

${ }^{* *}$ This paper was presented at the International Scientific Conference "Law in the context of addressing the Challenges of the Contemporary World", held at the Faculty of Law, University of Nišs, on $13^{\text {th }}-14^{\text {th }}$ April 2018.

This paper is part of the broader scientific project 'IMPULSE - Restructuring of Companies and the EU Law'supported by the Austrian Agency for International Cooperation in Education and Research - OeAD. Participants in this project were professors from the following universities: WU Vienna University of Economics and Business, University of Belgrade and 'Ss. Cyril and Methodius' University in Skopje.
} 
focus on the protection of individual employees' rights in the events of collective redundancies and transfer of undertakings/change of employers.

Key words: collective redundancies, transfer of undertakings, businesses, parts of undertakings or businesses, change of employers.

\section{Introduction}

In the contemporary labour law system of the Republic of Macedonia, the issue of collective redundancies is regulated by the Labour Relations Act of $2005^{1}$ (which is still in force). The term 'collective redundancies' itself, has been introduced for the first time by the amendments to the Labour Relations Act of $2010 .{ }^{2}$ The frequent changes to the legal provisions regulating the issue of collective redundancies are the result of certain 'internal' and 'external' reasons (Мръчков, Средкова, Василев, 2016: 414). The internal reasons stem from the need to mitigate the negative consequences of collective redundancies on workers. Such consequences have been affecting Macedonian workers since the independence of the country (in 1991), while they had their strongest impact in the so-called phase of 'transition' and 'privatization of the social capital' in the 1990s.The external reasons for continuous changes in the regulation of collective redundancies are a reflection of the need for harmonization of the Macedonian labour legislation, both with the international labour standards ${ }^{3}$ and the EU labour law (particularly with Council Directive 98/59/EC on collective redundancies) ${ }^{4}$.Hence, in thispaper, the authors will focus on the more 'problematic' issues arising from the system of regulation and implementation of collective redundancies in the country. In this regard, particular emphasis will be put on those segments of the collective redundancies regime which are not harmonized, are not properly harmonized, are not clear enough, and create confusions in their implementation.

1 The title of the legal provision regulating the issue of collective redundancies within the Original text of the Labour Relations Act of 2005 states: „Notification obligations in case of termination of employment of larger number of workers due to business reasons". For more information, see: Law on Labour Relations, Official Gazette of the Republic of Macedonia, no.62/05, Article 95.

2 The current title of the legal provision regulating the issue of collective redundancies pursuant to the Act amending and supplementing theLabour Relations Act, Official Gazette of the Republic of Macedonia, no.124/10, states: „information and consultation about collective redundancies due to business reasons".

3 In this context, particular focus should be given to the ILO Convention on Termination of Employment, 1982(No.156)and the ILO Recommendation on Termination of Employment, 1963 (No.119), which are ratified by the Parliament of the Republic of Macedonia.

4 See:Council Directive 98/59/EC on the approximation of the laws of the Member States relating to collective redundancies, Official Journal L 225, 12/08/1998 P. 0016 - 0021. 
In the modern businessenivronments, labour relations become increasingly dynamic and, as a consequence, there are more frequent changes on the side of the employer as a contractual party in the employment relationship. Usually, such changes are related to changes in the organization of the business and/or in the ownership of assets with which the business is being performed and which are directed towards a greater competitiveness and more efficient fulfilment of the employers' business objectives. The change of the employer can lead to a transfer of the employment contracts of the employees and safeguarding of their employment relationships only as a consequence of a so called 'transfer of an undertaking, part of an undertaking, business or part of a business' from the employer-predecessor (transferor) to the employer-successor (transferee). The second substantial issue which will be treated in this paper is the analysis of the compliance of the Macedonian labour legislation with the EU labour law (and in particular with the Directive 2001/23/EC on safeguarding of employees' rights in the event of transfers of undertakings, businesses, parts of undertakings or businesses), concerning the legal regime for regulating the transfer of undertakings and the protection of employees' individual rights. ${ }^{5}$

\section{Collective Redundancies}

\subsection{Forms (ways) of terminating employment contracts within the frame of collective redundancies - Definition and Scope}

The Labour Relations Act defines the collective redundancies by taking into consideration their quantitative and temporal aspects, or the aspects referring to the number of employees encompassed in the collective redundancy and to the period of time over which the collective redundancy is supposed to be carried out. In this regard, Macedonian labour legislation is aligned with the EU Directive 98/59/EC on collective redundancies, since it provides that collective redundancies should cover at least 20 employees for a period of 90 days. ${ }^{6}$

The biggest gap between Macedonian labour legislation and the EU labour law can be found in the scope of the 'collective redundancies' and particularly in the forms (ways) of terminating of employment contracts of employees that can be equated to redundancies.

5 See: Council Directive 2001/23/EC on the approximation of the laws of the Member States relating to the safeguarding of employees' rights in the event of transfers of undertakings, businesses or parts of undertakings or businesses, Official Journal L 082 , 22/03/2001 P. $0016-0020$.

6 Закон за работните односи, член 95, став 1. 
On the basis of the definition of collective redundancies as regulated by the Labour Relations Act, we come out with two different interpretations regarding the scope of collective redundancies. Such interpretations are: the broader (sensu latu) or grammatical interpretation, and the narrower (strictu sensu) interpretation.

The broader (sensu latu) interpretation of the scope of collective redundancies, implicitly entails all the forms of termination of employment contracts. If all the forms of termination of employment contracts are calculated in the number of redundancies, then this would mean that even terminations which are inherent to the individual worker concerned shall be considered as redundancies as well (e.g.: termination due to the employee's death; dismissals due to capacity or conduct reasons on the side of the employee, etc.).Such an interpretation is inadequate and contrary to the provisions and the spirit of the Directive 98/59/ EC on collective redundancies.

Unlike the broader (sensu latu) interpretation of the scope of collective redundancies which refers to 'any termination of the employment relationship', the narrower (sensu strictu) interpretation limits the scope of collective redundancies at precisely defined ways (cases) of termination of employment relationships. On the basis of this interpretation, the Labour Relations Actrefers to the 'decision on termination of employment due to business reasons ${ }^{77}$ asthe only way to terminate the validity of the employment contract that could be subsumed under the collective redundancy. The occurrence of the 'dismissal due to business reasons' as a single way of termination that can be equated to redundancy is contrary to the provisions and the spirit of the Council Directive 98/59/EC, which takes a broader (more extensive) approach. This means that the EU labour law establishes a Community concept of collective dismissals which is autonomous and uniform, and it cannot be derogated by the different national legislations of the EU member-states(Blanpain, 2012: 744). According to this concept, collective redundancies cannot be restricted only to redundancies for structural, technological or cyclical reasons and they have to comprise the dismissals for any reason not related to individual workers concerned. In fact, collective redundancies should comprise any termination of contract of employment not sought by the worker and therefore without his consent, but at the same time, it is not necessary that the underlying reasons should reflect the will of the employer. ${ }^{8}$

7 Ibidem.

8 Such an interpretation derives from the Judgment of the European Court of Justice in the case 'European Commission v Republic of Portugal' (C-55/02, Judgment dated 12.10.2004, Rec. 32), where the Court extends the scope of the collective redundancies to other cases (ways) of termination of employment based on specific 'external' circumstances, which are independent from the will or the initiative of the employer. Such other cases are those due to: 
De lege ferenda, under 'collective redundancy', Macedonian labour legislation should envisage all the ways of termination of employment contracts that are not related to the individual workers concerned and that are initiated by the employer, including the termination of the fixed-term employment contracts where such a termination takes place prior to the date of expiry or the completion of such contracts. It should also be borne in mind that there should be at least 5 employees of the total number of 'surplus' workers whose contracts of employment should be terminated on the basis of dismissal due to business reasons. The termination of the employment relationships of the remaining workers (necessary for meeting the statutory minimum in order to achieve the quantitative presumptions of the collective redundancy) may be established both on additional decisions on termination of employment due to business reasons as well as on consensual cancellations of the employment contracts(Crnčič, Cvetanovič, Gotovac, Gašpar Lukič, Milkovič, Tadič, Zuber, Žic, 2010: 178)

\subsection{Workers' participation in the event of collective redundancies}

Workers' participation in the event of collective redundancies entails the workers' rights to information and consultation, with its ultimate goal to prevent (mitigate) the consequences arising from the termination of the employment contracts of the 'redundant' (surplus) workers encompassed by the collective redundancy.

While Macedonian labour legislation is characterized by a proper harmonization with the EU labour law in terms of the 'temporal aspects' which determine the moments of initiation and completion of the information and consultation procedure, this conclusion cannot be brought in respect to the subjects who are involved in that procedure. Namely, workers' participation (information and consultation), both according to the Council Directive 98/59/EC as well as to the Labour Relations Act is indirect, with the involvement of workers' representatives. However, in Macedonian labour legislation there is neither substantial definition nor a procedure for the election of workers' representatives in regards to rights to participation. In such circumstances, the following question may be asked: Who are the subjects responsible for conducting the information and consultation procedure prior to the commencement of the collective redundancy? In practice, it is considered that trade unions (trade union representatives) can act in the capacity of workers' representatives, but what if there is no trade union organization at the employer? Yet, regardless of the fact whether workers are represented by the trade unions or by workers' representatives, they have

employer's insolvency, expropriation, fire or other cases of force majeure, as well as the cases of termination of undertakings' activities due to the death of the employer-natural person. 
an inalienable right to be informed and consulted, while employers have an obligation to involve the workers in the process of participation prior to the commencement of the collective redundancy. Such a position is aligned with the stance of the European Court of Justice taken in the European Commission $v$ United Kingdom case, where the Court states that it is no longer possible that there are no workers' representatives in the event where a Member State would not have an overall system of workers' representation. ${ }^{9}$

\subsubsection{The informing of workers' representatives in the event of collective redundancies}

There is a misalignment between the Macedonian labour legislation and the EU Directive 98/59/EC in relation to the contents that make the information and then the consultation of the employees, since the Labour Relations Act does not impose obligation to the employer to inform the workers' representatives on a very important issue such as the issue of the criteria for the selection of the workers to be made redundant. The determination of the selection criteria aims to objectify the process of selection of workers whose employment contracts shall be terminated or safeguarded. For the largest part of its validity, the current Labour Relations Act of 2005 has not 'touched' upon the issues related to selection of employees in the events of dismissals due to business reasons, including the cases of collective redundancies. ${ }^{10}$ The legal void has been settled in practice by the competent courts. Referring to the international labour standards (the ILO Convention on Termination of Employment No.158, and especially the ILO Recommendation on Termination of Employment No.166), in the event of dismissal due to business reasons, the Courts oblige the employer to determine certain criteria in advance (prior to the dismissal) for the selection of employees whose employment relationship shall be terminated. ${ }^{11}$ In the event that collective agreements which provide for criteria for selection of the employees are not applicable to the employer, he/she is obliged to determine, prior to the commencement of the procedure for termination of the employment contracts due to business reasons, certain criteria and measures with an internal Act, as well as to apply such criteria and measures (Томановиќ T, Томановиќ B, 2010: 111).

9 See: Case European Commission v. United Kingdom(C-382/92).

10 The latest Act ammending and supplementing the LRA of 29.06.2018 (Official Gazette of the Republic of Macedonia, no.120/2018) introduces a new provision that sets certain selection criteria (Art.7). In any case, we note that the provision is vague and unclear from a terminological point of view.

11 See: Decision of the Basic Court in Tetovo, P0. бр. 42/2013 from 03.07.2013 год. 
The latest Act amending and supplementing the Labour Relations Act of $29^{\text {th }}$ July 2018 stipulates the following selection criteria in terms of dismissal due to business reasons: the criteria arising from the needs for efficient functioning of the employers' work, vocational training and qualification of the employee, work experience, work performance, the type and significance of the employe's working position, length of service and other criteria determined in the collective agreement, including the criteria for protection of disabled persons, single parents and parents of children with special needs whose employment is terminated due to the same reasons. ${ }^{12}$ In practice, there are several collective agreements (primarily concluded at a branch level, that is, department level) which stipulate criteria and measures for the selection of employees with the priority of retaining their working position. In most of them, the prevalent criteria are: vocational training and qualification, length of service, type and value of the working position, work results, age and similar criteria. ${ }^{13}$ There are also collective agreements which provide for certain social criteria (such as, health condition or economic and social position of the employee), but although these are stipulated in the agreements, such criteria are given less value compared to the other criteria mentioned above. ${ }^{14}$

\subsubsection{Consultation of the workers' representatives in the event of collective redundancies}

The consultations begin only after informing the workers' representatives, but at least one month prior to the commencement of the collective redundancies. ${ }^{15}$ The purpose of the consultations is the 'reaching of an agreement' between the employer and the workers' representatives with regards to the ways and means for avoiding

12 See: Act ammending and suplementing the Labour Relations Act of 29.06.2018, Art.7.

13 Collective Agreements that envisage such criteria are: Collective Agreement for the Employees in the Food Industry (Колективен Договор за вработените од земјоделство и прехрамбена индустрија); Collective Agreement for the Textile Industry (Колективен Договор за текстилна индустрија на Република Македонија); Collective Agreement for the public facilities for children in the field of care and education of children (Колективен Договор за јавните установи за деца во дејноста згрижување и воспитание на децата и во дејноста одмор и рекреација на децата), еtс.

14 Collective Agreements that envisage such criteria are: Collective Agreement of companies of other monetary intermediation and the activity of intermediation in operations with securities and commodity contracts (Колективен Договор на друштвата од друго монетарно посредување и дејноста на посредување во работењето во хартии од вредност и стокови договори); Collective Agreement for Culture (Колективен Договор за култура); Collective Agreement for the Elementary Education (Колективен Договор за основното образование во Република Македонија), еtc.

15 Закон за работните односи, член 95, став 2. 
collective dismissals, reducing the number of dismissed workers, or mitigating the effects of the collective redundancies. ${ }^{16}$ The Labour Relations Actdetermines the general time frame during which the consultations between the employer and the workers' representatives should be conducted, but it does not provide for any specific details regarding: the way of conducting the consultations(written or oral) and the extent to which the parties are involved in the consultation procedure.

Usually, in practice, consultations start with the submission by the employer of a so-called 'draft program for fostering the redundant employees'. Workers' representatives are entitled to submit their opinions and proposals on the basis of the Draft Program. However, the Macedonian labour legislation does not determine the existence of such a 'program' as an act of the employer for fostering the redundant employees, nor does it determine its contents.

Concerning the extent to which the parties are involved in the consultation procedure, it remains unclear whether the consultations will be reduced to a simple exchange of opinions or will include a more in-depth form of dialogue between the parties which will resemble acollective bargaining. In our view, the employer will need to demonstrate goodwill, readiness and determination to finding a mutually acceptable solution even if at the end no agreement is reached.

\subsection{Notifying the public authorities for the planned collective redundancy}

The legal regime of collective redundancy in the Macedonian legal system is completed with the obligation of employers to notify the public authorities about the planned collective redundancy. Through the notification procedure, collective redundancies and their consequences are taken 'outside of the company boarders' because they have a wider social impact, tangling a wider range of subjects (Мрчков, 2012:644).In this process, the role of the public authority (which in the case of Macedonia is the Service responsible for employment intermediation, i.e.the Employment Service Agency of the Republic of Macedonia) is set to three broader competencies and activities,such as: the competence of being informed by the employerabout the planned collective redundancies, the competence of determining the time period for which the duration of the decisions for termination of the employment of the workers covered by the collective redundancies will not have a legal effect,and the activity of searchingfor solutions to the problems and consequences arising from the planned collective redundancies (Blanpain,2012:751). Through these three groups of competencies and activities, we analyze the compliance of the Macedonian labour legislation with the Council Directive 98/59/EC.

16 Закон за работните односи, член 95, став 3. 
The Labour Relations Act determines an obligation for the employer after the completion of the consultations with the workers'representative to notify in writing the service responsible for employment intermediation.... In the same provision, the law determines that the notification contains all relevant information regarding the planned collective redundancies and consultations with the workers' representatives.$^{17}$ In this part, the Macedonian labour legislation is complementary with the contentsand with the spirit of the Council Directive 98/59/EC, which first presumes the completion of the consultation procedure, and then the adoption of decisions on the termination of the employment relationship of workers covered by the collective redundancy. Such interpretation arises from the Junk v Kühnel (C-188/03)case, where the ECJ statesthat 'the notification of public authorities must follow the completion of the consultation procedure, while the dismissals can be made only after the completion of the notification procedure to public authorities'. Therefore, 'the purpose of the notification is not to prevent an employer from adoption of a decision for collective redundancy, but only the prevention of the unemployment of the employees covered by it'. ${ }^{18}$

While the initial part of the notification procedure of the public authorities is in line with the relevant provisions of the Council Directive 98/59/EC, it cannot be ascertained for the rest of it.The Council Directive 98/59/EC delegates the authority to the competent public administrative body to determine the time period for which the planned collective redundancies will not have a legal effect. In this regard, the earliest period in which collective redundancies can have a legal effect is 30 days from the moment of notification to the body of the public authority, ${ }^{19}$ and if this body estimates that the problems arising from collective redundancy cannot be resolved within the initial deadline, it has the right to extend this deadline to 60 days. ${ }^{20}$ Of course, the time period for notification of the public administrative body to the planned dismissals until their implementation should be used to seek solutions to problems arising from collective redundancies in relation to the workers. The Macedonian labour legislation 'makes an attempt' to align with this part of the notification procedure. However, it seems that the legislator did not understand the essence of the deadlines for the 'suspension' of carrying out the collective redundancy, i.e. the temporary prolongation of the individual dismissals of the workers encompassed by the collective redundancy.

17 Seе Закон за работните односи, член 95, став 6.

18 See: Opinion of the Attorney General, in the caseECJ27 Jan. 2005, Case C Irmtraud Junk v Wolfgang Kühnel - 188/03 ECR 2005.

19 See: Council Directive 98/59/EC, Article 4, paragraph 1.

20 See: Council Directive 98/59/EC, Article 4, paragraph 3. 
The purpose of determining the deadlines for 'temporary suspension' of the legal consequences of the collective redundancy decision is implicitly regulated in the Labour RelationsAct. In fact, for the duration of these deadlines, the Service responsible for employment intermediation requires an opportunity to provide assistance and services for labour mediation of workers covered by the collective redundancy, in accordance with the law (in particular, the Act on Employment and Insurance in case of Unemployment). ${ }^{21}$

\section{Transfer of undertakings}

\subsection{Legal reasons for transfer of an undertaking (cases of change of the employer)}

According to the EU Transfer of Undertakings Directive 2001/23/EC, the transfer of an undertaking/part of the undertaking/business/part of business can be a result of a legal transfer or merger. ${ }^{22}$ The legal basis for the transfer of an undertaking should reflect a 'contractual relationship' between the transferor and the transferee. Directive 2001/23/EC and its rules concerning the preservation of employment and safeguarding the employees' acquired rights shall be applied in all the cases that will result in an agreed change of the employer (legal entity or natural person).It means that every legal act on the basis of which there is a transfer of the employer's function may be subsumed under Directive 2001/23/ EC and covered by its rules.

The Labour RelationsAct of Macedonia regulates this issue by taking the respective provision from the Directive 'word for word'. Being willing to 'harmonize' with the Directive, the Act determines the legal reasons for transfers of undertakings, but it does that in a way which does not correspond with the legal terminology that is subject to regulation of the Acton Trade Companies ${ }^{23}$, and then with other regulations in the field of the broader contract law. The Labour Relations Act envisages the 'status changes ${ }^{24}$, as 'cases' on the basis of which a change of employer may occur on the one hand, as well as the 'legal transfers' or 'mergers' 25 on the otherhand. From the point of view of the Macedonian legal system, it seems that the notion 'legal transfer' is too general and can include different ways of transfer of undertakings, i.e. different cases of a change of an

21 Seе: Закон за вработување и осигурување во случај на невработеност, Сл. весник на Република Македонија по.37/1997

22 Council Directive 2001/23/EC, paragraph 1 (a).

23 Закон за трговските друштва, Сл.весник на Република Македонија, бр.28/04.

24 Seе: Закон за работните односи, Чл. 68, став 1.

25 Seе: Закон за работните однос,Чл. 68-а. 
employer, while the notion 'merger' is one of the possible types of status changes that are present in the Macedonian company law.

\subsection{Determining the subject of transfer and retaining the identity of the undertaking}

If a comparison is made between the 'subject of transfer' regulated with the Directive 2001/23/EC (which is the undertaking/part of the undertaking, business/part of the business) ${ }^{26}$ and the notion 'subject of transfer' according to the Labour Relations Act (which is a trade company or parts of a trade company), ${ }^{27}$ we will face an obvious terminological and crucial non-compliance between these two acts. The 'trade company' is and can only be a subject to law, and not an object, that is to be put in a legal circulation and to be subject of transfer (Беличанец, Миладинова, 2011: 78). Such an object (subject) could only be the 'undertaking', defined as a collection of rights, assets and factual relations that have a property value and that belong to the trade business of the merchant, which is an entire and independent legal entity that can be put in circulation. ${ }^{28}$ In short, the undertaking is a unity of property and people, connection of capital and labour, under a sole management directed towards achieving the economic objectives that have been set.

The transfer of the employment contracts of the employees is dialectically related to the fulfilment of another cumulative condition and that is the condition of the 'transferred undertaking to retain its identity' (i.e. the economic wholeness). In this regard, the Directive 2001/23/EC stipulates that a transfer of undertaking/ part of an undertaking/business/part of a business is considered to be a transfer of an 'economic entity which retains its identity, meaning an organised grouping of resources which has the objective of pursuing an economic activity, whether or not that activity is central or ancillary'.29 The transferred undertaking will retain its identity if the new employer continues or resumes to carry out the business that was previously performed by the old employer (Blanpain, 2012: 759). The existence of other circumstances should be taken into consideration too, without prejudice to their 'relative weight' and impact on the qualification of one transfer as 'a transfer of undertaking that retained its identity'. ${ }^{30}$ In any

26 See: Council Directive 2001/23/EC, Article 1, paragraph 1.

27 Seе: Закон за работните односи, чл.68-а.

28 Закон за трговските друштва, Чл. 3, став 1, точка 40.

29 See: Council Directive 2001/EC, paragraph 1, (b)

30 Such circumstances may be: the type of undertaking or business; the fact whether or not the tangible assets of the business (such as: buildings or movable property) were transferred; the value of the tangible assets at the time of the transfer; whether or not the majority of the 
case, the basic prerequisite for having continuity in the employment is to have continuity in the performance of the business activities that fall in the 'hands' of the new, changed employer (Pitt, 1997: 242).

The Macedonian labour legislation follows the model of the Directive 2001/23/EC and, at least, is formally harmonized with the legal assumption of the Directive that the transfer of the employment contracts of the employees as a result of the transfer of the undertaking depends inter alia on the retaining of the identity of the transferred undertaking. The Labour RelationsActstipulates that the transfer of the trade company or part of the trade company means a transfer of an economic entity ' which retains its identity, meaning an organised grouping of resources which has the objective of pursuing an economic activity, whether or not that activity is central or ancillary'. ${ }^{31}$

A crucial question in terms of the transfer of the undertakings and maintenance of their identity is solving the dilemmas coming from the ever expanding business practice of 'contracting out' of services (or outsourcing) in the EU member states. ${ }^{32}$ From the point of view of the EU labour law, the main problem of this business practice is the application or non-application of the regulations governing transfer of undertakings and their consequences for the employees in the event of a 'transfer of service activities which may take place without any transfer of tangible or intangible assets from the transferor to the transferee' (Laulom, 2001: 153). Evidently, this type of 'outsourcing' refers to the contracting out of labour-intensive service activities. In short, a primary criterion for the application of the transfer of undertakings regulations is the existence of a transfer of tangible or intangible assets (property) from the employer-transferor to the employer-transferee. If in the specific case there is no such transfer (as in cases of transferring labour intensive activities), the employment contracts of the employees will be nevertheless transferred to the new employer if he takes over a 'substantial' part of the workforce of his predecessor. This will particu-

employees were taken over by the new employer; whether or not the customers were transferred and the degree of similarity between the activities carried on before or after the transfer and the period, if any, for which those activities were suspended (See: Case 24/85, 18.03.1986, Jozef Maria Antonius Spijkers v Gebroeders Benedik Abattoir CV et Alfred Benedik en Zonen BV, ECR 1119).

31 Seе: Закон за работните односи, Чл. 68-а, став 2.

32 At the time when the Directive 2001/23/EC was adopted, the business practice of a 'transfer of the performance of certain service-providing activities to external contractors' (for example: cleaning, catering, security, etc.) or so called 'contracting out' was not present to a large extent in the business and production activities of the European companies. However, at the end of the eighties from the last century, it started to take more significant place in the strategies of 'vertical disintegration' of companies as a consequence of their interest in reducing the costs and increasing the hiring and firing flexibility. 
larly apply to those economic sectors that encompass such economic activities which are not composed of specific operating resources (for example: catering, maintenance and cleaning, security), and the takeover of the workforce will be a sufficient criterion that will lead to a transfer. In other words, in the labour intensive sectors, the takeover of the employees is a decisive criterion for the existence of a transfer.

The business practices of 'contracting out' and their legal consequences in relation to the employees are not an 'open subject for discussion' only on the level of the European Communities. They are insolvable enigmas in the Macedonian labour and legal system, even though 'at first sight' the Labour Relations Act seems to give certain directions in favour of them being solved. So, the Act stipulates that in the event of the 'transfer of activities of a trade company or parts of a trade company or in case of transfer of tasks or part of them from the employertransferor to another employer-transferee, the rights and obligations deriving from employment shall be completely transferred to the employer-transferee to whom the transfer is made.The transfer of the rights and obligations deriving from the employment relationship takes place regardless of the legal reason and regardless of the fact whether the ownership rights are transferred to the transferee or not. The employer-transferee, as an employer, is authorized to continue to perform the tasks or activities of the previous employer or to perform similar tasks and activities. The tasks and activities related to production or services provision or similar activities offered by the legal entity or natural person on their behalf and on their responsibility in the facilities or premises determined for their performance shall be considered as tasks or activities of the employer ${ }^{\prime 3}{ }^{33}$ With this provision, the Labour Relations Act (consciously or unconsciously) makes a clear distinction between the notion 'undertaking/part of the undertaking/business/part of the business' that refers to the performance of the central or ancillary activity of the employer, and the notion 'activity/task' that refers to the performance of certain stable and regular production or service-providing activities that are not central, nor ancillary activities of the employer and that can be 'outsourced'. But, on the other hand, the consequences from the transfer of the 'activity/task' in relation to the employees are identical to the consequences from the transfer of the 'undertaking/ part of the undertaking/ business/ part of the business'. Both the first and the second case cause (or are supposed to cause) transfer of the employment contracts of the employees and safeguarding of their acquired rights. However, in practice, the legal consequences in relation to the employees that occur after the transfer of the activity/task has been realized are diametrically opposite to those stipulated in the Act. Usually, in the event when the employer decides to 'outsource' a certain activity or task to an external contractor (regardless of

33 Seе: Закон за работните односи, Чл. 68-а, став 4. 
whether the activity is capital-intensive or labour-intensive), the employment contracts of the employees who have been previously employed by the employer that organized the performance of the activity or task in question are terminated, or are taken over by the new employer, but under different (deteriorated) conditions than the conditions the employees previously had.

\subsection{Safeguarding the employment and preserving the conditions of the employment relationship}

The principle of safeguarding the employment relationships of employees and preserving their terms and conditions of employment in the event of a change of the employer is inspired by the idea of'legal succession' that has been known in the civil and commercial law for centuries, and has been later transmitted to the labour law (Мръчков, 2015: 311). The basic rule inspired from the Directive 2001/23/EC is that the 'transferor's rights and obligations arising from a contract of employment or from an employment relationship existing on the date of a transfer shall, by reason of such transfer, be transferred to the transferee., ${ }^{34}$ This rule does not have an identical transposition within the Macedonian labour legislation but, from several provisions of the Labour Relations Act, a conclusion can be drawn that the new employer (transferee) takes over all the rights and obligations deriving from the transferred employment contracts in an unchanged form and scope ${ }^{35}$ It is considered that the contracting parties (employees employed at the employer-predecessor and the new employer) should not conclude new employment contracts because those are not 'new' contracts, but it is a transfer of their 'old' contracts of employment which are automatically transferred to the new employer-successor. The rights and obligations of the employees before and after the transfer of their employment contracts should be seen as a whole. Thus, the rights arising from the continuity of the employees' employment relationship (i.e. the years of service) with both employers (the former one and his successor), such as the rights to a severance pay and a period of notice, are particularly important. Additionally, the principle of 'safeguarding the employment of the employees and the preservation of their employment conditions' entails all other rights that the employee had with the previous employer, including the rights to identical salary, salary structure and other material compensations that derive from the employment relationship (Blanpain, 2012: 783).

The criticisms that can be put forward to the Macedonian legislator in the regulation of this part of the legal provisions regarding the transfer of undertakings is that the Labour Relations Act did not determine the 'moment' when it comes

34 See Council Directive 2001/23/EC, Article 3, para 1.

35 Seе Закон за работните односи, Чл 68, став 1; Чл. 68, став 2. 
to the transfer of the employment contracts of the employees. It only provides that 'all the rights, obligations and responsibilities under the employment contract and the employment relationship shall be transferred to the new employer... ${ }^{36}$ From the point of view of the Macedonian law, the date (day) of the transfer of the undertaking can be considered the date (day) when the legal consequences of such a transfer occurred in accordance with the regulations governing the legal reason on the basis of which the transfer was carried out (for example, in the event of status changes the date of the transfer can be considered the date of the publication of the entry of the status change in the trade registry) (Недков, Беличанец, 2008: 374)

\subsubsection{Consent of the employee for the transfer of the employment contract}

The key question in the event of a transfer of an undertaking, i.e. change of the employer is the following: whether the replacement of one employer with another causes an automatic (ex lege) transfer of the employment contracts of the employees, or, the employees have the free disposition to 'block' the transfer of their employment contracts to the new employer? In its contents, Directive 2001/23/EC does not give an explicit solution to this dilemma, so 'part' of the answer to this question can be sought in the approach of the European Court of Justice. Compared to the decisions of some older cases (as for example of the 'Daddy's Dance Hall' case ${ }^{37}$ or the 'Berg' $\mathrm{case}^{38}$ ) in which the European Court of Justice has explicitly accepted the rule for automatic transfer of the employment contracts regardless of the will of the employees, in the 'Katsikas' case ${ }^{39}$ the Court alleviates its stance in the favour of the discretion right of the employees to 'object' to the transfer of their employment contracts. In this case, the European Court of Justice states that the rules for transfer 'must not oblige the employee to continue the employment relationship with the transfere ${ }^{440}$... 'because such an obligation would jeopardize the fundamental rights of the employee, who must be free to choose his employer and cannot be obliged to work for an employer whom he has not freely chosen'. ${ }^{41}$

36 Seе Закон за работните односи, Чл. 68, став 1.

37 In this case, the ECJ had the stance that 'the transfer of the employment contracts does not depend on the willingness of the contracting parties since it is subject to the interest of the public policy' See: Case 324/86, 10.02.1988, Daddy's Dance Hall A/S ECR 739.

38 In this case, the ECJ ascertains that 'the change of employer brings an automatic transfer of the obligations of the employer, from the transferor to the transferee', See: Joined Cases 144 and 145/87, 5.05.1988, Harry Berg and Johannes Theodorus Maria Busschers v Ivo Martin Besselsen, ECR 2559.

39 See: Joined cases C-132/91, C-138/91 and C-139/91, Grigorios Katsikas, IRLR 179.

40 Case Katsikas v Konstantidis, paragraph (31).

41 Case Katsikas v Konstantidis, paragraph (32). 
Apart from this stance (which is to a greater extent expected and acceptable), the Court does not solve the essential dilemma 'whether the employment contract or the employment relationship of the employee who has voluntarily refused the transfer of his employment contract to the transferee will continue to be applied with the original employer (transferor) or not'.

The Macedonian labour law system guarantees the principles of 'voluntarity' and 'consensuality' in the employment relationships (Старова, 2008: 342). In that regard, in the event of a transfer, the refusal of employees to continue the employment relationship with a new employer is complementary with the principle of freedom of work and employment guaranteed by the Constitutionof the Republic of Macedonia. ${ }^{42}$ However, the Labour Relations Actdoes not stipulate a single concrete provision for resolving the dilemmas arising from the 'automatic' (ex-lege) transfer of the employment contract of the employees. It does not sets forth the obligation of the transferor to give written notice to the employees entailed with the 'transfer' for the forthcoming transfer of their employment contracts to the transferee, nor does it prescribe a term within which all these employees would be able to give their consent for the transfer. In such circumstances, it is fully unclear what the outcome will be if the employees 'explicitly' or 'tacitly' refuse the transfer of their employment contracts to the new employer.

\subsection{Prohibition of dismissals}

In most cases, the transfers of the undertakings are followed by dismissals of employees entailed in such transfers (Laulom, 2001: 174). Hence, the provisions that govern the safeguarding of the employment of employees in the event of transfers inevitably envisage and regulate this situation. The legal framework with which the transfers are regulated refers to both the 'prohibited' and 'allowed' cases of termination of the employment contracts of the employees in question. In that regard, Directive 2001/23/EC 'prohibits' the dismissals of employees on the grounds of the transfer of the undertaking itself, but 'allows' the dismissals due to economic, technical or organizational reasons entailing changes in the workforce. ${ }^{43}$ The prohibition of dismissal of the employees exists in all the events in which a 'causal' link can be shown between the dismissal and the transfer of the undertaking (Pitt, 1997: 794). This prohibition is binding for both the transferor (referring to the dismissals before the transfer date) and the transferee (referring to the dismissals after the date of the transfer of the undertaking). This means that if the employee was dismissed because of the 'fact' that the undertaking has been transferred, this dismissal would be deemed illegal, regardless whether the dismissal was given to the employee

42 Устав на Република Македонија, Сл.весник на Република Македонија, бр.52/92.

43 See Council Directive 2001/23, Article 4, paragraph 1. 
by the employer-predecessor or the employer-successor(Frntič, Govič Pentič, Hanzelak, Milkovič, Novakovič Rožman, 2017:794).

The Macedonian labour legislation regulates the issue of 'termination of the employment contracts in the event of transfer of undertakings' following the model of the Directive 2001/23/EC. In analogy to the European labour legislation, the Macedonian labour legislation 'prohibits' the dismissals conducted with the sole reason being the transfer of the undertaking, but 'allows' the dismissals based on business grounds on the initiative of the employer (predecessor or successor). Employees have the right to protection in the event of dismissals or in the case of deterioration of their acquired rights due to reasons which are connected to the transfer of the undertaking, while the employers are responsible to indemnify for infringing the rights of the employees in such cases.

Apart from the general prohibition on dismissing employees due to the transfer, in practice there are examples of abuse of this prohibition. First and foremost, it concerns cases in which one company ceases to exist (by closure of the undertaking) but, at the same time (or in a very short period of time), it founds another company (newly established company) that continues to perform the same or similar business activities. The closure of the undertaking causes termination of the employment relationship of the employees (whose employment contracts most often formally and legally are terminated on the basis of 'consensual termination' which requires a consent of the employees concerned), while the newly established company becomes a new employer of the same employees who sign new employment contracts, but this time with less favorable conditions. If the employees give their consent to the 'consensual termination of their employment contracts', it seems that they would be in a 'stalemate' position, while the transfer of their employment contracts with all the acquired rights would be equal to a 'mission impossible'. In this case, the following dilemma arises: 'whether and how the rights of the employees may be protected from this type of obvious abuses of their continuity in the employment and their acquired rights'? In our view, de lege ferenda, safeguarding of employees' rights would be enabled only if the legislator (in future changes and amendments to the labour legislation) enacts a new provision by which the 'malevolent' avoidance of the employers to fulfil their obligations regarding the employees in the event of a change of the employer would be explicitly sanctioned ${ }^{44} \mathrm{~A}$ provision with such contents would enable the employee (who, after the consensual termination of the employment

44 For example, in the labour legislation of the Republic of Croatia, there is a provision with which the 'abuse' of employees' rights in the event of a transfer of undertakings is regulated in the following manner: the person who, with the transfer of an undertaking, part of undertaking, business or part of business or in any other way, malevolently, avoids to fulfill his/her obligations regarding the employee, upon the request of the employee, the competent 
relationship with the employer-predecessor, has concluded a new employment contract with the employer-successor on less favorable terms) to file a lawsuit for exercising the rights from the employment contract against the 'new' employer who has not 'formally' taken over the undertaking and, as a consequence, has 'malevolently' avoided the fulfillment of his obligations towards the employee, guaranteeing the acquired rights that the employee had with the previous employer (Frntič et al. 2017: 799).

\section{Conclusion}

Collective redundancies form an essential part of the legal regulations of the Republic of Macedonia that cover the termination of employment contracts by dismissals. In terms of changing economic circumstances and increased flexibility and deregulation of the labour markets, the dismissal protection of employees due to the ceasure of the need to perform some work(i.e. redundancy for business reasons) is faced by major challenges. The initial impressions after the comparative analyses between Council Directive 98/59/EC and the legal regime of collective redundancies in Macedonian labour legislation are 'in favor' of a successful and comprehensive harmonization of Macedonian labour law with the EU law. Yet, if an in-depth observation of the legal provisions in the Labour Relations Act is conducted and if a more profound cross-section of Macedonian labour law system is carried out, one can conclude that the legal regime of collective redundancies is far from a clear and coherent whole which entirely corresponds to the contents and meaning of the EU regulations on collective redundancies and their consequences in relation to the workers.

The basic aims of the legal regime for regulating the consequences in relation to employees of the transfer of the undertakings, both in terms of EU labour law and in terms of the Macedonian labour legislation, are: safeguarding the security and stability of the employment relationships of the employees; prohibition of dismissals due to the fact that there is a change of the employer, i.e. transfer of undertaking and preservation of the acquired employment conditions and rights that had existed before the change of the employer, i.e. transfer of the undertaking has taken place. In our opinion, considering the approach of the Macedonian legislator in the regulation of this legal matter, the current legal framework for safeguarding the employees' rights in the events of transfer of undertakings is partially harmonized with the Directive 2001/23/EC. In the absence of adequate national court practice through which it will be possible to examine and assess the court's position on all 'problematic' aspects of the legal provisions governing the transfer of undertakings, we consider that this paper

court will oblige this person to fulfill the obligations even in the event when the employment contract is not concluded with him/her.(Labor Law, Article 129) 
can serve as a useful guide for the correct interpretation of the legal framework for the safeguarding of employees' individual rights in the event of a transfer of undertakings in the Republic of Macedonia.

\section{References}

Беличанец, Т и Миладинова, Д. (2011). Заштита на правата на работниците во случај на статусна промена или пренесување на претпријатие, бизнис или дел од бизнис од едно во друго трговско друштво. Во Деловно Право, Година XII, Бр.25, Скопје

Blanpain, R. (2012), European Labour Law. Thirteenth Revised Version

Crnčič, I. Cvetanovič, Gotovac.V, Gašpar Lukič,M, Milkovič.D, Tadič.I, Zuber.M и Žic.I (2010), Veliki Komentar Novog Zakona o Radu. Vaša Knjiga, d.o.o, Zagreb.

Frntič F.D, Govič Pentič.I, Hanzelak.D, Milkovič.D, Novakovič.N I K.Rožman. (2017). Detaljni Komentar Zakona o Radu, (Biblioteka Radno Pravo)

Govič.I, Marinkovič Drača.D, D.Milkovič. (2010). Zakon o Radu - komentar, sudska praksa I ogledni primjeri, (Zagreb).

Laulom,S. (2001). The European Court of Justice in the Dialogue on Transfers of Undertakings: a Faillible Interlocutor? In Silvana Sciarra (ed), Labour Law in the Courts, National Judges and European Court of Justice (Hart Publishing, 2001)

Мръчков,В. (2015). Трудово право. Сиби, 9 издание

Мръчков.В, Средкова.К, А.Василев. (2017).Коментар на Кодекса на труда, (Сиби, 12 издание)

Недков,М и Беличанец,T. (2008). Право на Друштвата. USAID, Скопје

Pitt,G. (1997). Employment Law. Third Edition

Старова, Г. (2008). Трудово Право, Просветно Дело А.Д Скопје.

Томановиќ,Т и Томановиќ, В. (2011). Договор за Работа, Скопје.

Legal Sources

Council Directive 98/59/EC on the approximation of the laws of the Member States relating to collective redundancies, Official Journal L 225 , 12/08/1998

Council Directive 2001/23/EC on the approximation of the laws of the Member States relating to the safeguarding of employees' rights in the event of transfers of undertakings, businesses or parts of undertakings or businesses, Official Journal L 082 , 22/03/2001 P. 0016 - 0020 
Устав на Република Македонија, Сл.весник на РМ” бр.52/92 (Constitution of the Republic of Macedonia, Official Gazette of the Republic of Macedonia, no.52/92).

Закон за работните односи,"Сл.весник на РМ” бр. 62/05 (Labour Relations Act, 'Official Gazette of the Republic of Macedonia, no. 62/05).

Закон за трговските друштва, “Сл.весник на PM” бр. 28/04(Trade Companies Act,Official Gazette of the Republic of Macedonia no. 28/04'

\section{Case law}

Case C-188/03, 27 January 2005, Irmtraud Junk v Wolfgang Kühnel

Case C-55/02, 120ctober 2001, Commission of the European Communities $v$ Portuguese Republic

Case C-382/92, 8 June 1994, Commission of the European Communities v United Kingdom of Great Britain and Northern Ireland

Case 324/86, 10.02.1988, Daddy's Dance Hall

Case 24/85, 18.03.1986, Jozef Maria Antonius Spijkers v Gebroeders Benedik Abattoir CV et Alfred Benedik en Zonen BV

Joined cases C-132/91, C-138/91 and C-139/91, Grigorios Katsikas.

Joined Cases 144 and 145/87, 5.05.1988, Harry Berg and Johannes Theodorus Maria Busschers v Ivo Martin Besselsen. 


\section{Др Тодор Каламатиев,}

Редовни професор,

Правни факултет „Јустинијан Први",

Универзитет „Св.Кирил и Методиј” Скопље,

Република Македонија

Др Александар Ристовски,

Доцент

Правни факултет,Јустинијан Први“,

Универзитет „Св.Кирил и Методиј” Скопље,

Република Македонија

\section{ЗАШТИТА ПРАВА РАДНИКА У СЛУЧАЈЕВИМА КОЛЕКТИВНОГ ОТПУШТАҢА И ПРОМЕНЕ ПОСЛОДАВЦА: КЉУЧНИ АСПЕКТИ УСКЛАЪИВАЊА ПРАВА ЕУ И МАКЕДОНСКОГ РАДНОГ ПРАВА}

\section{Резиме}

У складу да обавезама које проистичу из Споразума о стабилизацији и придруживању из 2001. године, који је закључен између држава чланица Европске уније и Републике Македоније, држава спроводи континуирану хармонизацију свог правног поретка са правом ЕУ, која обухвата и законске прописе из такозваног "социјалног" асquis соттипаи taire. С тим увези, аутори овог рада анализирају кључне аспекте Директиве 98/59/ЕУ о колективном отпуштању и Директиве 2001/23/ЕУ о заштити права запослених у случају промене послодавца, преносу предузећа или дела предузећа, и њихове имплементације у радно законодавство Републике Македоније, са посебним освртом на заштиту индивидуалних права запослених у случају колективног отпуштања и промене промене послодаваца.

Кључне речи: Колективно отпуштање; пренос предузећа или дела предузећа; промена послодавца. 
